\title{
PELANGGARAN KODE ETIK DAN PEDOMAN PERILAKU HAKIM
}

\author{
Kajian Putusan Nomor 63/Pid.B/2012/PN.TBL dan Nomor 64/Pid.B/2012/PN.TBL
}

\section{VIOLATION OF THE CODE OF ETHICS AND CODE OF CONDUCT OF JUDGES}

\author{
An Analysis of Court Decision Number 63/Pid.B/2012/PN.TBL \\ and Number 64/Pid.B/2012/PN.TBL
}

\author{
Imran \\ Pusat Studi Hak Asasi Manusia Universitas Islam Indonesia (PUSHAM-UII) \\ J1. Jeruklegi, Gg. Bakung No. 517 A, Pringgolayan, Banguntapan, Bantul, Yogyakarta 55198 \\ Email: imranpushamuii@yahoo.com
}

Naskah diterima: 6 Februari 2019; revisi: 7 Mei 2019; disetujui: 7 Mei 2019

http://dx.doi.org/10.29123/jy.v12i1.379

\section{ABSTRAK}

Dalam sistem peradilan pidana penanganan suatu kasus dimulai sejak kasus itu muncul, kemudian ditangani oleh polisi, hingga proses akhir dari penegakan hukum terletak pada putusan hakim. Putusan hakim dapat berupa menjatuhkan hukuman ataupun membebaskan seorang terdakwa. Dalam putusan hakim akan terlihat kemampuan hakim dalam mengonstruksi kasus sejak dakwaan dibacakan hingga pledoi diucapkan. Semua konstruksi hakim tersebut akan tergambar dalam pertimbangan-pertimbangan. Dalam pertimbangan tersebut akan terlihat apakah suatu putusan tersebut melanggar kode etik atau tidak. Apa yang terlihat dalam dua putusan hakim yang dikeluarkan oleh Pengadilan Negeri Tobelo, mencerminkan adanya persoalan ketika seorang terdakwa dua kali dihukum oleh majelis hakim yang sama untuk perbuatan yang sama pula. Hal inilah yang kemudian menjadi rumusan masalah, apakah putusan tersebut melanggar Kode Etik dan Pedoman Perilaku Hakim atau tidak? Dengan menggunakan metode penelitian hukum normatif yang memfokuskan kajian pada data sekunder, maka akan terlihat bagaimana sesungguhnya dua putusan tersebut. Hasil dari penelitian
\end{abstract}

ini menunjukkan telah terjadi pelanggaran Kode Etik dan Pedoman Perilaku Hakim yang dilakukan oleh majelis hakim.

Kata kunci: kode etik dan pedoman perilaku hakim, sistem peradilan pidana, profesionalisme.

\section{ABSTRACT}

In the criminal justice system, the handling of a case starts since the claim arises, then is handled by the police, until the final process of law enforcement, which lies in the judge's decision. Judges' decisions can be in the form of sentencing or acquitting a defendant. The ability of a judge to construct a case will appear in the decision from the time the indictment is read until the plea is pronounced. In these considerations, it will be seen whether the judge's decision violates the code of ethics or not. Two judges' decisions issued by the Tobelo District Court reflect the problem in which a defendant was twice sentenced by the same panel of judges for violating the same law. This is what then becomes the formula of the problem, whether the decision violates the Code of Ethics and Code of Conduct of Judges or not. By using normative legal research method focusing 
on secondary data construing, it will expose the fact of these two decisions. The results of this analysis indicate that there are violations of the Code of Ethics and Code of Conduct of Judges been committed by the panel of judges examining the case.

Keywords: code of ethics and code of conduct of judges, criminal justice system, professionalism.

\section{PENDAHULUAN}

\section{A. Latar Belakang}

Sistem peradilan di Indonesia masih menyimpan banyak persoalan. Mulai dari persoalan administratif, hingga persoalan substansif yang berkaitan dengan putusan hakim. Persoalan ini hingga hari ini tidak pernah terselesaikan secara tuntas dan dapat dilihat hasilnya sebagai bentuk dan upaya untuk menciptakan profesionalitas pengadilan, maupun meningkatnya kualitas para hakim. Akibatnya adalah lemahnya penegakan hukum dan rendahnya kualitas keadilan di negeri ini.

Salah satu persoalan yang kemudian muncul yaitu berkaitan dengan kasus yang terjadi di Pengadilan Negeri Tobelo. Kasus ini bermula pada tanggal 25 Maret 2012, Wakil Bupati Pulau Morotai serta rombongan Satpol PP yang mendatangi PT MMC di Pulau Ngele-Ngele Besar. Kedatangan wakil bupati tersebut yaitu untuk meminta penghentian kegiatan perusahaan. Namun dalam pertemuan tersebut tidak dicapai kesepakatan. Pada saat yang bersamaan SB, selaku Kepala Satuan Polisi Pamong Praja Kabupaten Pulau Morotai, mengadakan apel yang diikuti oleh anggota Satpol PP kurang lebih 50 orang.

SB kemudian memerintahkan ZI dan MSL bersama anggota Satpol PP lainnya, untuk mematikan diesel listrik, melepas dinamo yang berada di ruang pembibitan, serta melepas pelampung pada keramba ikan. Lalu, ZI dan MSL bersama anggota Satpol PP lainnya pergi ke ruang kamar mesin diesel, dan kemudian terdakwa merusak mesin diesel dengan cara memotong kabel penghubung baterai charger dengan accu, kemudian baterai charger diserahkan kepada SB, akibatnya listrik menjadi padam.

Dari kasus ini kemudian terjadi laporan oleh PT MMC ke Kepolisian Tobelo yang kemudian memunculkan perkara yang disidangkan di Pengadilan Negeri Tobelo dengan Putusan Nomor 63/Pid.B/2012/PN.TBL. Dua orang terdakwa kemudian di dakwa dengan dakwaan alternatif yaitu:

"Kesatu: Bahwa terdakwa I ZI dan terdakwa II MSL bersama-sama SB (terdakwa dalam berkas terpisah) pada hari Minggu tanggal 25 Maret 2012 sekitar jam 10.00 WIT atau setidak-tidaknya pada suatu waktu dalam bulan Maret 2012 bertempat di PT MMC tepatnya di Pulau Ngele-Ngele Besar Kecamatan Morotai Selatan Barat Kabupaten Morotai atau setidak-tidaknya pada suatu tempat yang masih termasuk dalam daerah hukum Pengadilan Negeri Tobelo dengan terang-terangan dan tenaga bersama menggunakan kekerasan terhadap orang atau barang. Perbuatan tersebut dilakukan terdakwa dengan cara-cara sebagai berikut:

Bahwa pada hari Minggu tanggal 25 Maret 2012 sekitar pukul 09.00 WIT para terdakwa bersama rombongan Wakil Bupati Pulau Morotai serta rombongan Satpol PP mendatangi kembali PT MMC Ngele-Ngele Besar setelah itu diadakan pertemuan dengan direktur PT MMC IR, namun tidak ada kesepakatan. Pada saat yang sama SB selaku Kepala Satuan Pamong Praja Kabupaten Pulau Morotai mengadakan apel yang diikuti terdakwa I 
ZI dan terdakwa II MSL dan juga anggota Satpol PP Kabupateb Pulau morotai dan atas arahan SB memerintahkan terdakwa I dan terdakwa II serta anggota Satpol PP Kabupaten Pulau Morotai untuk mematikan diesel listrik melepas dinamo yang berada di ruangan pembibitan serta melepas pelampung pada keramba ikan. Selanjutnya untuk menindaklanjuti hal tersebut kemudian SB, terdakwa I, dan terdakwa II serta anggota Satpol PP pergi ke ruang mesin diesel. SB memerintahkan terdakwa I dan terdakwa II untuk merusak mesin diesel dengan cara memotong kabel penghubung baterai charger dengan $a c c u$, kemudian baterai charger diserahkan kepada SB akibatnya listrik menjadi padam.

Perbuatan para terdakwa sebagaimana diuraikan di atas diatur dan diancam pidana Pasal 170 ayat (1) KUHP

atau

Kedua: Bahwa terdakwa I ZI dan terdakwa II MSL bersama-sama SB (terdakwa dalam berkas terpisah) pada hari Minggu tanggal 25 Maret 2012 sekitar jam 10.00 WIT atau setidak-tidaknya pada suatu waktu dalam bulan Maret tahun 2012 bertempat di PT MMC tepatnya di pulau Ngele-Ngele Besar Kecamtan Morotai Selatan Barat Kabupaten Morotai atau setidak-tidaknya pada suatu tempat yang masih termasuk dalam daerah hukum Pengadilan Negeri Tobelo dengan terang-terangan dan tenaga bersama menggunakan kekerasan terhadap orang atau barang. Perbuatan tersebut para terdakwa lakukan dengan cara-cara sebagai berikut:

Bahwa pada hari Minggu tanggal 25 Maret 2012 sekitar pukul 09.00 WIT para terdakwa bersama rombongan Wakil Bupati Pulau Morotai serta rombongan Satpol PP mendatangi kembali PT MMC Ngele-Ngele Besar setelah itu diadakan pertemuan dengan direktur PT MMC IR, namun tidak ada kesepakatan. Pada saat yang sama SB selaku Kepala Satuan Pamong Praja Kabupaten Pulau Morotai mengadakan apel yang diikuti terdakwa I ZI dan terdakwa II MSL dan juga anggota Satpol PP Kabupaten Pulau Morotai dan atas arahan SB memerintahkan terdakwa
I dan terdakwa II serta anggota Satpol PP Kabupaten Pulau Morotai untuk mematikan diesel listrik melepas dinamo yang berada di ruangan pembibitan serta melepas pelampung pada keramba ikan. Selanjutnya untuk menindaklanjuti hal tersebut kemudian SB, terdakwa I, dan terdakwa II serta anggota Satpol PP pergi ke ruang mesin diesel, SB memerintahkan terdakwa I dan terdakwa II untuk merusak mesin diesel dengan cara memotong kabel penghubung baterai charger dengan accu, kemudian baterai charger diserahkan kepada SB akibatnya listrik menjadi padam.

Perbuatan para terdakwa sebagaimana diuraikan di atas diatur dan diancam pidana Pasal 406 ayat (1) jo. Pasal 55 ayat (1) ke-2 KUHP."

Dari dakwaan ini kemudian majelis hakim memutuskan para terdakwa terbukti melanggar dakwaan kesatu, yaitu Pasal 170 ayat (1) KUHP yang berbunyi: "barang siapa yang di muka umum bersama-sama melakukan kekerasan terhadap orang atau barang, dihukum penjara selamalamanya lima tahun enam bulan." Putusan hakim menghukum para terdakwa selama satu tahun penjara. Namun kemudian ditemukan terdapat putusan yang sama dengan terdakwa yang sama pula dalam satu pengadilan yang sama, yaitu Putusan Nomor 64/Pid.B/2012/PN.TBL.

Putusan Nomor 64/Pid.B/2012/PN.TBL ada dua terdakwa yang diajukan dalam persidangan yaitu ZI dan MSL. Kedua terdakwa di persidangan didakwa alternatif yaitu: dakwaan kesatu diancam dengan pidana Pasal 170 ayat (1) KUHP dan dakwaan kedua diancam dengan pidana Pasal 406 ayat (1) jo. Pasal 55 ayat (1) ke-2 KUHP. Putusan hakim dalam perkara ini yaitu para terdakwa melanggar Pasal 170 ayat (1) KUHP dan dihukum selama satu tahun penjara

Dari kedua putusan di atas terlihat ada dugaan pelanggaran Kode Etik dan Pedoman 
Perilaku Hakim yang dilakukan oleh majelis hakim. Dugaan ini dikarenakan adanya kesamaan dari sisi administratif dan substantif putusan yang dikeluarkan oleh majelis hakim. Oleh karena itu sangat perlu untuk dianalisis lebih lanjut dugaan pelanggaran Kode Etik dan Pedoman Perilaku Hakim seperti apa yang dilakukan oleh majelis hakim.

\section{B. Rumusan Masalah}

Apakah dalam Putusan Nomor 63/ Pid.B/2012/PN.TBL dan Nomor 64/Pid.B/2012/ PN.TBL telah terjadi Pelanggaran Kode Etik dan Pedoman Perilaku Hakim?

\section{Tujuan dan Kegunaan}

Tujuan dan kegunaan dari penelitian ini yaitu: 1) secara teoritis penelitian ini diharapkan mampu memberikan sumbangan pemikiran bagi hakim dalam memutus perkara yang sama sesuai dengan Kode Etik dan Pedoman Perilaku Hakim; dan 2) secara praktis hasil dari penelitian ini diharapkan menjadi suatu kebijakan bagi hakim dalam memutus perkara yang berkaitan dengan perkara pidana.

\section{Tinjauan Pustaka}

Istilah "etika" menurut Bartens berasal dari bahasa Yunani kuno "etos" dalam bentuk tunggal yang berarti adat kebiasaan, adat istiadat, akhlak yang baik. Bentuk jamak dari ethos adalah ta etha artinya adat kebiasaan. Dari bentuk jamak inilah terbentuk kata "etika" yang oleh filsuf Yunani Aristoteles (384-322 SM) sudah dipakai untuk menunjukkan filsafat moral. Berdasarkan asal usul kata ini, maka etika berarti ilmu tentang apa yang biasa dilakukan atau ilmu tentang adat kebiasaan (Muhammad, 2006: 13). Sedangkan menurut Kamus Besar Bahasa Indonesia, etika adalah ilmu tentang apa yang baik dan apa yang buruk dan tentang hak dan kewajiban moral (akhlak) (Depdiknas, 2001: 309).

Etika dan moral sebenarnya mempunyai pengertian yang berbeda walaupun dalam pemakaiannya sehari-hari, etika dan moral seringkali digunakan dalam pengertian yang sama, yaitu tingkah laku, perbuatan, sikap yang baik, tegasnya menyangkut baik dan buruknya manusia (Magnis-Suseno, 1989: 9). Dengan demikian etika/moral adalah kerangka dalam semua aktivitas manusia. Apalagi jika manusia itu memiliki profesi tertentu maka secara otomatis aktivitasnya ada dalam kerangka etika/moral.

Magnis-Suseno dalam Tedjosaputro (2003: 36) mengemukakan lima kriteria nilai moral yang kuat mendasari kepribadian profesional hukum yaitu:

\section{Kejujuran}

Kejujuran adalah dasar utama, tanpa kejujuran maka profesional hukum mengingkari misi profesinya sehingga dia menjadi munafik, licik, penuh tipu diri. Dua sikap yang terdapat dalam kejujuran yaitu: (i) sikap terbuka. Ini berkaitan dengan pelayanan klien, kerelaan melayani secara bayaran atau cuma-cuma; dan (ii) sikap wajar. Ini berkenaan dengan perbuatan yang tidak berlebihan, tidak otoriter, tidak sok kuasa, tidak kasar, tidak menindas, dan tidak memeras.

2. Autentik

Autentik artinya menghayati dan menunjukkan diri sesuai dengan keasliannya, kepribadian yang sebenarnya. Autentik pribadi profesional hukum antara 
lain: (i) tidak menyalahgunakan wewenang; (ii) tidak melakukan perbuatan yang merendahkan martabat (perbuatan tercela); (iii) tidak mendahulukan kepentingan klien; (iv) berani berinisatif dan berbuat sendiri dengan bijaksana, tidak sematamata menunggu perintah atasan; dan (v) tidak mengisolasi diri dari pergaulan.

3. Bertanggung jawab

Dalam menjalankan tugasnya, profesional hukum wajib bertanggung jawab, artinya:

(i) kesediaan melakukan dengan sebaik mungkin tugas apa saja yang termasuk lingkup profesinya; (ii) bertindak secara proporsional tanpa membedakan perkara bayaran dan perkara cuma-cuma (prodeo).

\section{Kemandirian moral}

Kemandirian moral artinya tidak mudah terpengaruh atau tidak mudah mengikuti pandangan moral yang terjadi di sekitarnya, melainkan membentuk penilaian sendiri. Mandiri secara moral berarti tidak dapat dibeli oleh pendapat mayoritas, tidak terpengaruh oleh pertimbangan untung rugi (pamrih) menyesuaikan diri dengan nilai kesusilaan agama.

\section{Keberanian moral}

Keberanian moral adalah kesetiaan terhadap suara hari nurani yang menyatakan kesediaan untuk menanggung risiko konflik. Keberanian tersebut antara lain: (i) menolak segala bentuk korupsi, kolusi, suap, pungli; (ii) menolak tawaran damai di tempat atas tilang karena pelanggaran lalu lintas jalan raya; dan (iii) menolak segala bentuk cara penyelesaian melalui jalan belakang yang tidak sah.
Sebagai profesi yang mulia, hakim menggunakan sistem etika untuk menyediakan struktur yang mampu menciptakan disiplin tata kerja dan menyediakan garis batas tata nilai yang dapat dijadikan pedoman untuk menyelesaikan dilema ketika menjalankan profesinya seharihari. Dengan berbagai macam persoalan yang melingkupi hakim dan dunia peradilan saat ini maka dibutuhkan etika sebagai refleksi kritis tentang bagaimana manusia harus hidup dalam situasi konkret tertentu untuk menentukan sikap dan bertindak secara benar (Keraf, 2010: 18). Etika merupakan norma-norma yang dianut oleh kelompok, golongan atau masyarakat tertentu mengenai perilaku yang baik dan buruk. Etika merupakan refleksi kritis dan rasional mengenai norma-norma yang terwujud dalam perilaku hidup manusia baik secara pribadi maupun kelompok (Nuh, 2011: 224 ).

Profesional seorang hakim teletak pada tugas utamanya yaitu memeriksa, mengadili, dan memutus perkara. Putusan hakim merupakan tindakan akhir dari hakim di dalam persidangan, menentukan apakah dihukum atau tidak si pelaku, jadi putusan hakim adalah pernyataan dari seorang hakim dalam memutuskan suatu perkara di dalam persidangan dan memiliki kekuatan hukum tetap (Mulyadi, 2007: 127). Putusan hakim tidak bersifat statis, karena akan terkait dengan realitas yaitu berbagai kepentingan, kekuatan serta kekuasaan. Putusan hakim senantiasa kontekstual dan tidak bebas nilai (tidak netral) (Shidarta et al., 2014: 9). Oleh karena itu putusan hakim tersebut harus dapat menunjukkan kecerdasan nalar, rasa, hasrat, dan intuisi serta keberanian dalam memutus suatu perkara.

Dilihat dari sudut birokrasi peradilan, putusan hakim akan terkait dengan tiga kriteria, 
yaitu: efektivitas, efisiensi, dan kejujuran. Efektivitas dinilai dalam segi apakah putusan hakim mampu menjadi pilar hukum, artinya seberapa besar putusan pengadilan memberikan jawaban terhadap kegelisahan masyarakat. Efisensi terkait dengan pembiayaan dari apa yang dilakukan para hakim yang dihubungkan dengan apa yang mereka capai. Kejujuran berada diantara dua kategori dan merupakan masalah paling peka bagi masyarakat umum. Di sini perhatian terpusat pada bagaimana peradilan memperlakukan masyarakat atau mereka yang masuk dalam proses dengan sepantasnya secara hukum dan moral, tanpa mengindahkan keefektifan mereka dalam memutus perkara atau efisiensi mereka dalam mengurangi biaya (Shidarta et al., 2014: 8)

Oleh karena itu pengadilan dan hakim adalah dua komponen yang tidak terpisahkan, satu menjadi bagian yang lain. Hakim menjadi entitas yang utama yang memaknai kata "pengadilan" tempat diselenggarakannya proses yang disebut mengadili. Sementara pengadilan sebagai lembaga atau institusi dituntut untuk menyelenggarakan proses mengadili secara profesional dengan dukungan administrasi yang profesional pula (Rifai et al., 2007: 30).

Profesi hakim yang mulia tersebut membutuhkan sandaran etika yang mampu memberikan tuntutan pada tugas sehari-hari hakim, baik dalam lingkup administratif maupun dalam tugas untuk memeriksa, mengadili, dan memutus perkara. Karena perkembangan profesi mengimplikasikan kepada tuntutan-tuntutan norma etik yang melandasi persoalan profesional (Utomo, 1992: 1).

Hakim sebagai orang yang mengadili dan memutus suatu perkara bukan saja menjalankan apa yang termuat dalam undang-undang, tetapi harusnya mampu merekonstruksi undang-undang itu berdasarkan bukti fakta persidangan, nilai keadilan. Menurut Rahardjo, secara sosiologis ada dua macam hakim yaitu: Pertama, hakim yang mengadili perkara mendengarkan suara dan putusan hati nuraninya, baru kemudian mencari aturan hukum untuk menjadi landasan putusan nuraninya. Kedua, hakim yang memeriksa dan mendengarkan "suara perutnya" lebih dulu lalu dicarikan pasal-pasal untuk membenarkannya (Rahardjo, 2006: 93).

Putusan hakim merupakan suatu produk yang dihasilkan dalam suatu persidangan yang terbuka untuk umum, mempunyai makna penting bagi para pencari keadilan dalam peradilan pidana atau perdata. Putusan hakim di satu pihak berguna bagi terdakwa untuk memperoleh kepastian hukum tentang "statusnya," sedangkan di satu pihak putusan hakim merupakan "mahkota" sekaligus "puncak" pencerminan nilai-nilai keadilan; kebenaran hakiki; hak asasi manusia; penguasaan hukum atau fakta secara mapan, mumpuni dan faktual, serta visualisasi etika, mentalitas, dan moralitas dari hakim (Mulyadi, 2014: 129.)

Dalam memutus suatu perkara ada tiga aspek yang perlu dipertimbangkan oleh seorang hakim yaitu filosofis, yuridis, dan sosiologis. Menurut Muhammad, pertimbangan yuridis adalah pertimbangan hakim yang didasarkan pada fakta-fakta yuridis yang terungkap dalam persidangan dan oleh undang-undang ditetapkan sebagai hal yang harus dimuat di dalam putusan misalnya dakwaan penuntut umum, keterangan terdakwa, keterangan saksi, barang-barang bukti, dan pasal-pasal dalam peraturan hukum pidana. Hakim sebagai aplikator undang-undang, harus mencari undang-undang yang berkaitan dengan perkara yang sedang dihadapi. Hakim harus 
menilai apakah undang-undang tersebut adil, ada kemanfaatannya atau memberikan kepastian hukum jika ditegakkan, sebab salah satu tujuan hukum itu unsurnya adalah menciptakan keadilan (Muhammad, 2007: 212 ).

Aspek filosofis merupakan aspek yang berintikan pada kebenaran dan keadilan, sedangkan aspek sosiologis mempertimbangkan tata nilai budaya yang hidup dalam masyarakat. Aspek filosofis dan sosiologis, penerapannya sangat memerlukan pengalaman dan pengetahuan yang luas serta kebijaksanaan yang mampu mengikuti nilai-nilai dalam masyarakat yang terabaikan. Jelas penerapannya sangat sulit sebab tidak mengikuti asas legalitas dan tidak terikat pada sistem. Pencantuman ketiga unsur tersebut tidak lain agar putusan dianggap adil dan diterima masyarakat (Rifai, 2010: 126)

Sebagai bagian dari profesi terhormat dalam mengadili perkara, hakim juga memiliki kode etik agar ia mampu menjaga diri dan profesinya dari "godaan" yang dapat memberinya stigma amoral. Stigma amoral seringkali dirasakan oleh hakim karena terindikasi berbuat tidak adil. Profesi hakim harus mempunyai kode etik agar nilai-nilai yang terdapat di dalam peraturan perundang-undangan terinternalisasi pada diri seorang hakim. Nilai-nilai tersebut mencakup beberapa hal sebagai berikut:

1. Hakim dalam menjalankan tugasnya harus bebas, tetapi harus menjunjung tinggi keadilan.

2. Hakim harus menjunjung tinggi nilainilai keterbukaan dan menemukan hukum melalui metode interpretasi.

3. Hakim harus selalu mempertanggungjawabkan sikap dan tindakannya baik secara vertikal (kepada Tuhan Yang Maha Esa) maupun secara horizontal (masyarakat).
4. Hakim harus bersedia menerima keberatan yang diajukan oleh pihak yang diadili apabila meragukan objektivitas hakim tersebut (KHN RI, 2003: 38).

Terdapat sepuluh prinsip dalam aturan perilaku yang termuat dalam Kode Etik dan Pedoman Perilaku Hakim yang ditandatangani bersama oleh Mahkamah Agung dan Komisi Yudisal dalam bentuk keputusan bersama. Sepuluh prinsip tersebut yaitu: 1) Berperilaku adil; 2) Berperilaku jujur; 3) Berperilaku arif dan bijaksana; 4) Bersikap mandiri; 5) Berintegritas tinggi; 6) Bertanggung jawab; 7) Menjunjung tinggi harga diri; 8) Berdisiplin tinggi; 9) Berperilaku rendah hati; dan 10) Bersikap profesional. Kesepuluh prinsip ini merupakan kewajiban hakim untuk memelihara kehormatan, keluhuran martabat, dan menjaga marwah dari godaan-godaan yang dapat merusak perilaku sehari-hari hakim. Kesepuluh prinsip ini harus dijalankan secara konkret dan konsisten baik dalam tugas yudisialnya maupun di luar tugas yudisialnya sebab hal ini berkaitan dengan upaya penegakan hukum dan keadilan. Paling tidak ada tiga sebab mengapa kode etik dirumuskan yaitu: 1) sebagai sarana kontrol sosial; 2) sebagai pencegah campur tangan pihak lain; dan 3) sebagai pencegah kesalahpahaman dan konflik (Muhammad, 2006: 78).

\section{METODE}

Penelitian ini menggunakan metode penelitian hukum normatif, yang memfokuskan kajian pada norma hukum (Soekanto \& Mamudji, 2011: 13). Sifat penelitian ini adalah preskriptif, memberikan penilaian mengenai sesuatu yang seharusnya dilakukan (Marzuki, 2014: 69-70). Pendekatan yang digunakan dalam penelitian ini adalah pendekatan kasus (case apporach), yaitu 
dengan mengkaji alasan-alasan hukum yang meliputi pertimbangan hukum dan kemampuan membangun penafsiran hukum oleh hakim dalam membuat suatu putusan atau penetapan (Marzuki, 2014: 158-166).

Bahan hukum primer dalam penelitian ini adalah Putusan Nomor 63/Pid.B/2012/PN.TBL, dan Nomor 64/Pid.B/2012/PN.TBL. Sedangkan bahan hukum sekunder dalam penelitian ini berupa buku dan jurnal hukum yang relevan dengan tema penelitian. Beberapa bahan hukum tersebut akan dijadikan sebagai bahan hukum yang berguna menjawab pokok masalah dalam penelitian ini. Dalam kegiatan analisis, penulis akan menganalisis pertimbangan hukum dari masing-masing majelis hakim dalam Putusan Nomor 63/Pid.B/2012/PN.TBL dan Nomor 64/ Pid.B/2012/PN.TBL.

Pisau analisis yang digunakan adalah menggunakan bahan hukum sekunder seperti penggunaan buku dan jurnal serta Kode Etik dan Pedoman Perilaku Hakim. Hasil analisis akan dijadikan dasar untuk membangun argumentasi yang menjawab pokok masalah dalam penelitian, yang bersamaan dengan itu, penulis juga sekaligus memberikan preskriptif berdasarkan argumentasi yang terbangun.

\section{HASIL DAN PEMBAHASAN}

Penegakan hukum dipahami dan diyakini sebagai aktivitas menerapkan norma-norma atau kaidah-kaidah hukum positif terhadap suatu peristiwa konkret. Penegakan hukum bekerja seperti model mesin otomatis, di mana pekerjaan menegakkan hukum menjadi aktivitas subsumsi otomat, hukum dilihat sebagai variabel yang jelas dan pasti yang harus diterapkan pada peristiwa yang juga jelas dan pasti (Rahardjo, 2004: 173).
Salah satu lembaga penegak hukum yaitu pengadilan memiliki peran yang sangat penting dalam implementasi konsep negara hukum. Pengadilan merupakan institusi pelaksana konstitusi, perlindungan hak asasi manusia, dan jaminan atas prosedur-prosedur yang adil. Sebagai suatu gambaran yang ideal dalam menjalankan fungsi pengadilan atau peninjauan konstitusi, para hakim tidak hanya menangani konflik antara elite politik, tetapi juga mampu menghindari pelaksanaan kekuasaan pemerintahan yang tidak adil serta memberikan perlindungan terhadap hak-hak masyarakat. Dengan demikian, pengadilan menjadi pelaku yang sangat kuat dalam memelihara kekuasan negara melalui jalur hukum (Asrun, 2004: 45).

Peranan pengadilan tidak dapat disangsikan lagi, sebab dengan lembaga pengadilan inilah segala yang menyangkut hak dan tanggung jawab yang terabaikan dapat diselesaikan, lembaga ini memberikan tempat bahkan membantu kepada mereka yang dirampas hak-haknya dan memaksa kepada pihak-pihak agar bertangung jawab atas perbuatan yang dilakukan yang merugikan pihak lainnya. Aktivitas lembaga pengadilan demikian itu pada dasarnya adalah berupaya mewujudkan rumusan-rumusan hukum yang sifatnya abstrak ke dalam kenyataan masyarakat (Muhammad, 2006: 4).

Sistem peradilan pidana di Indonesia menempatkan polisi, jaksa, dan hakim serta lembaga pemasyarakatan sebagai penegak hukum pidana. Sistem peradilan pidana merupakan suatu jaringan (network) peradilan yang menggunakan hukum pidana sebagai sarana utamanya, baik hukum pidana materiel, hukum pidana formal maupun hukum pelaksanaan pidana. Namun demikian kelembagaan substansial ini harus dilihat dalam kerangka atau konteks sosial. 
Sifatnya yang terlalu formal apabila dilandasi hanya untuk kepentingan kepastian hukum saja akan membawa kepada ketidakadilan (Muladi, 1995: 18).

\section{Menurut Reksodiputro (1993: 15)} tujuan sistem peradilan pidana adalah: a) Mencegah masyarakat menjadi objek/korban; b) Menyelesaikan kasus kejahatan yang terjadi sehingga masyarakat puas bahwa keadilan telah ditegakkan dan yang bersalah dipidana; dan c) Mengusahakan agar mereka yang pernah melakukan kejahatan tidak mengulangi lagi kejahatannya.

Konstruksi perkara pidana dimulai ketika prosespenyelidikandanpenyidikanyangkemudian menetapkan tersangka terhadap dugaan tindak pidana. Setelah proses yang lengkap tersebut maka terdakwa dan barang bukti akan diserahkan oleh polisi kepada kejaksaan negeri untuk kemudian disusun dakwaan dan dilimpahkan ke pengadilan negeri setempat. Terhadap berkas perkara yang telah dilimpahkan ke pengadilan negeri maka panitera akan memberikan nomor register yang kemudian diserahkan ke ketua pengadilan untuk ditetapkan penunjukan majelis hakim yang akan memeriksa dan mengadili perkara tersebut (MA RI, 2007: 228).

Dengan alur perkara yang begitu ketat, maka mustahil akan muncul perkara yang sama dengan terdakwa yang sama dan di pengadilan yang sama, karena bila perkara itu masuk pengadilan maka ketua pengadilan akan mempelajari perkara tersebut, jika ditemukan sesuatu yang tidak benar maka ketua pengadilan akan memerintahkan panitera untuk mengembalikan berkas perkara tersebut ke pihak kejaksaan.

Hal yang sama juga dilakukan oleh majelis hakim yang telah ditunjuk untuk mempelajari berkas dakwaan secara formal maupun materiel. Dari pembacaan berkas dakwaan tersebut kemudian majelis hakim yang ditunjuk akan menentukan jadwal persidangan. Jika hakim pemeriksa perkara yang telah ditunjuk menemukan sesuatu yang dianggap tidak benar maka majelis hakim pemeriksa perkara dapat berkonsultasi dengan ketua pengadilan negeri setempat.

Dalam Putusan Nomor 63/Pid.B/2012/ PN.TBL, ada tiga orang yang dihadirkan sebagai saksi, yaitu: IR, SA, dan PT. Sedangkan untuk Putusan Nomor 64/Pid.B/2012/PN.TBL ada enam orang saksi yang dihadirkan oleh jaksa penuntut umum yaitu: IR, SA, PT, IM, NRK, dan NK. Ada tiga orang saksi yang sama dan dalam kesaksiannya dalam prsidangan ditemukan keterangan yang sama dalam dua perkara tersebut.

Pertimbangan terhadap dakwaan jaksa penuntut umum dilakukan oleh majelis hakim dua putusan ini yang sesuai dengan fakta-fakta dalam persidangan. Dijelaskan dalam putusan, fakta-fakta yang terungkap dalam persidangan sesuai dengan dakwaan kesatu, yaitu melanggar Pasal 170 KUHP ayat (1) dengan unsur-unsurnya sebagai berikut: a) barang siapa; b) di muka umum; c) bersama-sama melakukan kekerasan terhadap barang. Dalam pertimbangan majelis hakim dalam dua perkara ini, dari ketiga unsur tersebut semuanya terbukti telah dilakukan oleh para terdakwa. Seperti yang tertulis dalam Putusan Nomor 63/Pid.B/2012/PN.TBL di bawah ini:

"Menimbang bahwa berdasarkan pertimbangan-pertimbangan tersebut di atas ternyata perbuatan para terdakwa telah memenuhi unsur dari dakwaan kesatu sehingga majelis hakim berkesimpulan bahwa para terdakwa telah terbukti sacara sah dan meyakinkan bersalah melakukan 
tindak pidana yang didakwakan kepadanya yaitu melanggar Pasal 170 ayat (1) KUHP yang dikualifikasikan sebagai tindak pidana "dimuka umum secara bersama-sama melakukan kekerasan terhadap barang."

"Menimbang bahwa dari kenyataan yang diperoleh selama persidangan dalamperkara ini majelis hakim tidak menemukan halhal yang dapat melepaskan para terdakwa dari pertanggungjawaban pidana dalam dakwaan kesatu tersebut sebagai alasan pembenar dan atau alasan pemaaf, oleh karenanya majelis hakim berkesimpulan bahwa perbuatan para terdakwa harus dipertanggungjawabkan kepadanya."

"Menimbang bahwa oleh karena para terdakwa mampu bertanggung jawab maka para terdakwa harus dinyatakan bersalah atas tindak pidana yang didakwakan terhadap dirinya dan oleh karena itu harus dijatuhi pidana."

Pertimbangan yang sama dapat dilihat dalam Putusan Nomor 64/Pid.B/2012/PN.TBL yaitu:

"Menimbang bahwa berdasarkan pertimbangan-pertimbangan tersebut di atas ternyata perbuatan para terdakwa telah memenuhi unsur dari dakwaan kesatu sehingga majelis hakim berkesimpulan bahwa para terdakwa telah terbukti sacara sah dan meyakinkan bersalah melakukan tindak pidana yang didakwakan kepadanya yaitu melanggar Pasal 170 ayat (1) KUHP yang dikualifikasikan sebagai tindak pidana "dimuka umum secara bersama-sama melakukan kekerasan terhadap barang."

"Menimbang bahwa dari kenyataan yang diperoleh selama persidangan dalam perkara ini majelis hakim tidak menemukan halhal yang dapat melepaskan para terdakwa dari pertanggungjawaban pidana dalam dakwaan kesatu tersebut sebagai alasan pembenar dan atau alasan pemaaf, oleh karenanya majelis hakim berkesimpulan bahwa perbuatan para terdakwa harus dipertanggungjawabkan kepadanya."

"Menimbang bahwa oleh karena para terdakwa mampu bertanggung jawab maka para terdakwa harus dinyatakan bersalah atas tindak pidana yang didakwakan terhadap dirinya dan oleh karena itu harus dijatuhi pidana."

Di bawah ini adalah tabel yang membandingkan beberapa hal yang sama dari dua putusan tersebut yaitu:

Tabel 1. Perbandingan Putusan Nomor 63/Pid.B/2012/PN.BTL dan Nomor 64/Pid.B/2012/PN.BTL

\begin{tabular}{|c|c|c|c|c|}
\hline \multirow{2}{*}{ No. } & \multirow{2}{*}{ Uraian } & \multicolumn{2}{|c|}{ Putusan Nomor } & \multirow{2}{*}{ Keterangan } \\
\hline & & 63/Pid.B/2012/PN.TBL & 64/Pid.B/2012/PN.TBL & \\
\hline 1. & Identitas terdakwa & $\begin{array}{ll}\text { a. } & \text { ZI } \\
\text { b. } & \text { MSL }\end{array}$ & $\begin{array}{l}\text { a. } \mathrm{ZI} \\
\text { b. } \mathrm{MSL}\end{array}$ & Sama \\
\hline 2. & $\begin{array}{l}\text { Surat penetapan ketua } \\
\text { pengadilan negeri } \\
\text { tentang penunjukan } \\
\text { majelis hakim pemeriksa } \\
\text { perkara }\end{array}$ & $\begin{array}{l}\text { Nomor 63/Pen.Pid/2012 } \\
\text { tertanggal } 14 \text { Agustus } 2012\end{array}$ & $\begin{array}{l}\text { Nomor 64/Pen.Pid/2012 } \\
\text { tertanggal } 14 \text { Agustus } 2012\end{array}$ & $\begin{array}{l}\text { Berbeda } \\
\text { nomornya saja }\end{array}$ \\
\hline 3. & Masa penahanan & $\begin{array}{l}\text { a. } 27 \text { Mei s.d. } 26 \text { Mei } 2012 \\
\text { b. } 27 \text { Mei s.d. } 13 \text { Mei } 2012 \\
\text { c. 01 Juni s.d. 08 Juni } 2012 \\
\text { d. 08 Juni s.d. 16 Juni } 2012 \\
\text { e. Dikeluarkan 16 Juni } 2012\end{array}$ & $\begin{array}{l}\text { a. } 07 \text { Mei s.d. } 26 \text { Mei } 2012 \\
\text { b. } 27 \text { Mei s.d. } 13 \text { Mei } 2012 \\
\text { c. } 01 \text { Juni s.d. 08 Juni } 2012 \\
\text { d. 08 Juni s.d. 16 Juni } 2012 \\
\text { e. Dikeluarkan 16 Juni } 2012\end{array}$ & $\begin{array}{l}\text { Sama, hanya ada } \\
\text { salah ketik }\end{array}$ \\
\hline 4. & Tempus dan locus delicti & $\begin{array}{l}\text { Tanggal } 25 \text { Maret } 2012 \text { di } \\
\text { Pulau Ngele-Ngele Morotai }\end{array}$ & $\begin{array}{l}\text { Tanggal } 25 \text { Maret } 2012 \text { di } \\
\text { Pulau Ngele-Ngele Morotai }\end{array}$ & Sama \\
\hline
\end{tabular}




\begin{tabular}{|c|c|c|c|c|}
\hline 5. & Uraian dakwaan & Sedikit & Lebih rinci & $\begin{array}{l}\text { Substansi sama } \\
\text { tapi yang satu } \\
\text { lebih rinci }\end{array}$ \\
\hline 6. & $\begin{array}{l}\text { Dasar dakwaan } \\
\text { (alternatif) }\end{array}$ & $\begin{array}{l}\text { a. Pasal } 170 \text { ayat (1) KUHP } \\
\text { b. Pasal } 406 \text { ayat (1) jo. } \\
\text { Pasal } 55 \text { ayat (1) ke-2 } \\
\text { KUHP }\end{array}$ & $\begin{array}{l}\text { a. Pasal } 170 \text { ayat (1) KUHP } \\
\text { b. Pasal } 406 \text { ayat (1) jo. } \\
\text { Pasal } 55 \text { ayat (1) ke-2 } \\
\text { KUHP }\end{array}$ & Sama \\
\hline 7. & Pertimbangan & Sama & Sama & Sama \\
\hline 8. & Dakwaan yang terbukti & $\begin{array}{l}\text { Dakwaan kesatu Pasal } 170 \\
\text { ayat (1) KUHP }\end{array}$ & Pasal 170 ayat (1) KUHP & Sama \\
\hline 9. & Amar putusan & $\begin{array}{l}\text { Menjatuhkan pidana } \\
\text { terhadap para terdakwa oleh } \\
\text { karena itu dengan pidana } \\
\text { penjara masing-masing } \\
\text { selama satu tahun }\end{array}$ & $\begin{array}{l}\text { Menjatuhkan pidana } \\
\text { terhadap para terdakwa oleh } \\
\text { karena itu dengan pidana } \\
\text { penjara selama satu tahun }\end{array}$ & Beda \\
\hline 10. & Tanggal musyawarah & 13 Desember 2012 & 13 Desember 2012 & Sama \\
\hline 11. & Pembacaan putusan & 13 Januari 2013 & 13 Januari 2013 & Sama \\
\hline 12. & Susunan majelis hakim & $\begin{array}{l}\text { a. AHM (Ketua) } \\
\text { b. EMA } \\
\text { c. DFCHS }\end{array}$ & $\begin{array}{l}\text { a. AHM (Ketua) } \\
\text { b. EMA } \\
\text { c. DFCHS }\end{array}$ & Sama \\
\hline 13. & Panitera pengganti & $\mathrm{NH}$ & MB & Beda \\
\hline
\end{tabular}

Sumber: Direktori Putusan Mahkamah Agung

Apa yang terlihat dari dua putusan yang sama tersebut menunjukkan kemampuan hakim dalam memberikan pertimbangan. Bisa dicermati dari 13 item dalam tabel 1 yang dipersandingkan oleh penulis, terlihat hanya tiga hal yang berbeda yaitu: nomor penetapan penunjukan majelis hakim, amar putusan, dan panitera pengganti. Selain itu semuanya sama baik secara formal maupun materiel.

Dari sisi formal nama terdakwa, dakwaan, masa penahanan, dan tempus delicti sama. Menunjukkan perkara ini sesungguhnya memiliki kronologis yang sama, artinya kasus ini kemudian dipisah berkas perkara (splitsing) dan dijadikan dua kasus yang berbeda. Splitsing yang merupakan kewenangan jaksa penuntut umum sesuai dengan Pasal 142 KUHAP berbunyi: "dalam hal penuntut umum menerima satu berkas perkara yang memuat beberapa tindak pidana yang dilakukan oleh beberapa orang tersangka yang tidak termasuk dalam ketentuan Pasal 141, penuntut umum dapat melakukan penuntutan terhadap masing-masing terdakwa secara terpisah." Artinya splitsing dilakukan jika lebih dari suatu perbuatan dan pelaku serta locus delicti perbuatan tersebut.

Menurut Harahap, pemecahan berkas perkara ini dulu disebut splitsing. Memecah satu berkas perkara menjadi dua atau lebih atau $a$ split trial (Harahap, 2016: 442). Pada dasarnya pemecahan berkas perkara terjadi disebabkan faktor pelaku tindak pidana terdiri dari beberapa orang. Apabila terdakwa terdiri dari beberapa orang, penuntut umum dapat menempuh kebijaksanaan untuk memecah berkas perkara menjadi beberapa berkas sesuai dengan jumlah terdakwa, sehingga:

a. Berkas yang semula diterima penuntut umum dari penyidik, dipecah menjadi dua atau beberapa berkas perkara. 
b. Pemecahan dilakukan apabila yang menjadi terdakwa dalam perkara tersebut, terdiri dari beberapa orang. Dengan pemecahan berkas dimaksud, masing-masing terdakwa didakwa dalam surat dakwaan yang berdiri sendiri antara yang satu dengan yang lain.

c. Pemeriksaan perkara dalam pemecahan berkas perkara, tidak lagi dilakukan bersamaan dalam suatu persidangan. Masing-masing terdakwa diperiksa dalam persidangan yang berbeda.

d. Pada umumnya, pemecahan berkas perkara menjadi penting, apabila dalam perkara tersebut kurang bukti dan kesaksian.

Dalam perkara ini splitising justru dilakukan terhadap orang yang sama, padahal jelas sekali dalam dakwaan baik untuk Putusan Nomor Nomor 63/Pid.B/2012/PN.BTL dan Nomor 64/ Pid.B/2012/PN.BTL kronologis kasus sama, dan orang yang didakwa pun sama, sehingga tidak sepantasnya kasusnya dibuat menjadi dua kasus yang berbeda dengan masa hukuman yang berbeda pula.

Dalam pertimbangannya pun tidak terlihat hal-hal yang membedakan dua perkara ini, yang dapat menunjukkan kemampuan hakim untuk menyelesaikan kasus secara adil. Hakim hanya memberikan pertimbangan yang seadanya saja tanpa mengagli lebih dalam kasus tersebut. Putusan Nomor 64/Pid.B/2012/PN.BTL sangat kental disalin dari Putusan Nomor 63/Pid.B/2012/ PN.BTL.

Penggunaan hukum materiel dan fakta persidangan yang begitu dominan tanpa merujuk pada sumber hukum di luar perundang-undangan seperti yurisprudensi maupun doktrin. Sangat terlihat dalam dua putusan ini kering dari literatur maupun rujukan, baik berupa yurisprudensi maupun doktrin yang dijadikan dasar hakim dalam memberikan pertimbangan, tidak hanya mencocokkan apa yang ada dalam fakta persidangan dengan aturan dalam pasal-pasal KUHP.

Menurut Sidartha (2000: 206), prosesproses pembuatan putusan tidak dapat dilepaskan dari kegiatan bernalar hakim. Kegiatan bernalar dari hakim dengan beragam motivering yang menopangnya, selalu berada dalam pusaran tarikan keanekaragaman kerangka orientasi berpikir yuridis yang terpelihara dalam sebuah sistem autopusis, sehingga dapat berkembang menurut logikanya sendiri, dan eksis sebagai sebuah model penalaran yang khas sesuai dengan tugas-tugas profesionalnya.

Tugas profesional hakim tersebut juga bersandar pada kode etik hakim. Dalam Kode Etik dan Pedoman Perilaku hakim angka 10 termuat pengaturan tentang sikap profesional yang bermakna: "suatu sikap moral yang dilandasi oleh tekad untuk melaksanakan pekerjaan yang dipilihnya dengan kesungguhan, yang didukung oleh keahlian atas dasar pengetahuan, keterampilan, dan wawasan luas. Sikap profesional akan mendorong terbentuknya pribadi yang senantiasa menjaga dan mempertahankan mutu pekerjaan, serta berusaha untuk meningkatkan pengetahuan dan kinerja, sehingga tercapai setinggi-tingginya mutu hasil pekerjaan, efektif, dan efisien."

Dari bunyi kode etik ini aspek profesionalisme merupakan salah satu aspek yang harus dimiliki seorang hakim agar dapat menjalankan tugas, fungsi, dan wewenangnya dengan baik. Profesionalisme hakim dapat dilihat dari aspek penguasaan ilmu hukum, kemampuan 
berpikir yuridis, kesadaran serta komitmen profesional. Jika dilakukan maka putusan ini dapat menghindari hakim dari kekeliruan yang tidak perlu seperti kasus di atas.

Selain persoalan profesional, putusan hakim merupakan bagian dari penegakan keadilan. Menurut Kelsen, keadilan adalah suatu kualitas yang berhubungan tidak dengan isi perintah positif, melainkan dengan pelaksanaannya. Keadilan berarti menjaga berlangsungnya perintah positif dengan menjalankannya secara bersungguh-sungguh (Djohansjah, 2008: 56). Seperti juga yang dikatakan oleh Manan, bahwa hakim bukanlah mulut undang-undang atau mulut hukum positif pada umumnya, melainkan hakim adalah mulut kepatutan, keadilan, kepentingan umum, dan ketertiban umum. Apabila penerapan aturan hukum akan bertentangan dengan kepatutan, keadilan, kepentingan umum atau ketertiban umum, hakim wajib memilih kepatutan, keadilan, kepentingan umum, dan ketertiban umum (Manan, 2004: 63).

Pada kasus ini sesungguhnya ada tiga tahap yang dilanggar yaitu:

1. Tahap pertama, pada saat perkara telah diregister ini dimasukkan kepada ketua pengadilan untuk ditentukan majelis hakim pemeriksa perkara. Sebagaimana dalam Peraturan Mahkamah Agung Nomor 7 Tahun 20015 tentang Organisasi dan Tata Kerja Kepaniteraan dan Kesekretariatan Peradilan, dalam Pasal 1 ayat (2) menyebutkan ketua pengadilan melaksanakan pengawasan terhadap penyelenggaraan peradilan di peradilan tingkat banding dan peradilan tingkat pertama yang dibantu oleh wakil ketua pengadilan. Hal yang sama juga diatur dalam Buku II tentang Pedoman Tugas dan Administrasi Pengadilan dalam Empat Lingkungan Peradilan, yang menyebutkan ketua pengadilan negeri memeriksa berkas perkara yang telah diregister dan diserahkan oleh panitera muda pidana (MA RI, 2007: 228). Pada tahap ini seharusnya ketua pengadilan negeri dapat mencermati Putusan Nomor 64/Pid.B/2012/PN.TBL sama dengan putusan sebelumnya yang telah diputus oleh majelis hakim. Pada tahap ini ketua pengadilan negeri tidak melakukan pengawasan yang cermat ketika menunjuk kembali majelis hakim yang sama dengan perkara sebelumnya

2. Pada tahap kedua ketika majelis hakim memeriksa Putusan Nomor 64/Pid.B/2012/ PN.TBL dengan majelis yang sama, dan waktu persidangannya juga berdekatan, maka tidak mungkin hakim tidak paham atas perkara ini. Dalam Buku II tentang Pedoman Tugas dan Administrasi Pengadilan dalam Empat Lingkungan Peradilan disebutkan, sebelum perkara disidangkan majelis hakim terlebih dahulu memeriksa berkas perkara untuk mengetahui apakah surat dakwaan memenuhi syarat formal dan materiel. Jika diketahui tidak memenuhi syarat maka surat dakwaan dikembalikan ke penuntut umum untuk diperbaiki. Pada tahap ini seharusnya majelis hakim dapat memberikan catatan terhadap kasus ini dengan menjelaskan kasus yang sama sudah pernah diperiksa dan diputus (nebis in idem) sehingga penuntut umum tidak lagi mengajukan perkara yang sama ke persidangan.

3. Pada tahap ketiga ketika memeriksa dan memutus Putusan Nomor 64/Pid.B/2012/ 
PN.TBL, yang mana pada tahap ini majelis hakim sudah dapat mencermati dari perkara sebelumnya yang semuanya sama. Pada tahap ini terlihat hakim dengan sengaja membiarkan persidangan terus berjalan hingga memeriksa saksi-saksi dan menjatuhkan putusan akhir. Berarti majelis hakim telah membiarkan dua orang terdakwa dihukum atas perbuatan yang sama dan telah diputus pada persidangan sebelumnya.

Dari tiga tahapan pelanggaran tersebut, Kode Etik dan Pedoman Perilaku Hakim yang dilanggar yaitu: 1.1.(8) "hakim harus memberikan keadilan kepada semua pihak dan tidak beriktikad semata-mata untuk menghukum" dan bersikap profesional "bermakna suatu sikap moral yang dilandasi oleh tekad untuk melaksanakan pekerjaan yang dipilihnya dengan kesungguhan yang didukung oleh keahlian atas dasar pengetahuan, keterampilan, dan wawasan luas. Sikap profesional akan mendorong terbentuknya pribadi yang senantiasa akan menjaga dan mempertahankan mutu pekerjaan serta berusaha untuk meningkatkan pengetahuan dan kinerjanya sehingga tercapai setinggi-tingginya mutu hasil pekerjaan, efektif, dan efisien."

\section{KESIMPULAN}

Dari dua putusan yang dianalisis oleh penulis dapat ditarik kesimpulan sebagai berikut: Pelanggaran Kode Etik dan Pedoman Perilaku Hakim dalam putusan ini terlihat dalam Putusan Nomor 64/Pid.B/2012/PN.TBL yang dilakukan dalam tiga tahap, yaitu: ketika perkara diperiksa oleh ketua pengadilan negeri; ketika perkara dilimpahkan ke majelis hakim untuk diteliti surat dakwaannya; dan pada saat putusan akhir yang tetap menghukum para terdakwa dengan hukuman yang sama, padahal perkara yang sama telah diputus sebelumnya.

Pada tahap pertama ketua pengadilan negeri yang menerima berkas perkara tidak memeriksa secara teliti berkas perkara tersebut sebelum menyerahkan berkas perkara tersebut ke majelis hakim pemeriksa perkara. Padahal ketua pengadilan negeri menunjuk majelis hakim yang sama untuk memeriksa, mengadili, dan memutus perkara tersebut, artinya kepala pengadilan negeri paham atas perkara tersebut.

Pada tahap kedua ketika surat dakwaan diteliti majelis hakim pemeriksa perkara sudah langsung dapat mengetahui adanya berkas yang sama dari sisi formal maupun materiel atas perkara tersebut. Pada tahap ketiga ketika pemeriksaan dilakukan hingga putusan dibacakan seharusnya majelis hakim sudah dapat menyimpulkan perkara ini sama dengan perkara sebelumnya, sehingga putusannya tersebut tidak dua kali dijatuhkan kepada para terdakwa.

\section{DAFTAR ACUAN}

Asrun, A.M. (2004). Krisis peradilan Mahkamah Agung di bawah Soeharto. Jakarta: Elsam.

Departemen Pendidikan Nasional (Depdiknas). (2001). Kamus Besar Bahasa Indonesia. Jakarta: Balai Pustaka.

Djohansjah, J. (2008). Reformasi Mahkamah Agung: Menuju independensi kekuasan kehakiman. Jakarta: Kesaint Blanc.

Harahap, Y. (2016). Pembahasan permasalahan \& penerapan KUHAP (Penyidikan \& penuntutan). Jakarta: Sinar Grafika. 
Keraf, A.K. (2010). Etika lingkungan hidup. Jakarta: Kompas.

Komisi Hukum Nasional Republik Indonesia (KHN RI). (2003). Laporan akhir standar disiplin profesi. Jakarta: KHN RI.

Magnis-Suseno, F. (1989). Etika sosial. Jakarta: Gramedia.

Mahkamah Agung Republik Indonesia (MA RI). (2007). Pedoman pelaksanaan tugas \& administrasi pengadilan dalam empat lingkungan pengadilan. Jakarta: Mahkamah Agung Republik Indonesia.

(2009). Pedoman pelaksanaan tugas \& administrasi pengadilan dalam empat lingkungan peradilan. Buku II. Jakarta: Mahkamah Agung Republik Indonesia.

Manan, B. (2004). Hukum positif Indonesia (Satu kajian teoritik). Yogyakarta: FH UII Press.

Marzuki, P.M. (2014). Penelitian hukum. Jakarta: Prenada Media Group.

Muhammad, A. (2006). Etika profesi hukum. Bandung: Citra Aditya Bakti.

Muhammad, R. (2006). Potret lembaga peradilan di Indonesia. Jakarta: PT Raja Grafindo Persada. . (2007). Hukum acara pidana kontemporer. Bandung: PT Citra Aditya Bakti.

Muladi. (1995). Kapita selekta sistem peradilan pidana. Semarang: BP Undip.

Mulyadi, L. (2007). Kompilasi hukum pidana dalam perspektif teoritis \& praktek peradilan. Bandung: Mandar Maju.

(2014). Seraut wajah putusan hakim dalam hukum acara pidana Indonesia; Perspektif, teoritis, praktik, teknik membuat \& permasalahannya. Bandung: Citra Aditya Bakti.
Nuh, M. (2011). Etika profesi hukum. Jakarta: Pustaka Setia.

Rahardjo, S. (2004). Sosiologi hukum perkembangan metode \& pilihan masalah. Surakarta: Muhamadiyah Universtiy Press. . (2006). Membedah hukum progresif. Jakarta: Kompas.

Reksodiputro, M. (1993). Sistem peradilan pidana Indonesia (Melihat kepada kejahatan \& penegakan hukum dalam batas-batas toleransi). Jakarta: FH UI.

Rifai, A. (2010). Penemuan hukum oleh hakim dalam perspektif hukum progresif. Jakarta: Sinar Grafika.

Rifai, A., et al. (2007). Wajah hakim dalam putusan. Yogyakarta: Pusham-UII, NCHR, \& Komisi Yudisial Republik Indonesia.

Shidarta, et al. (2014). Disparitas putusan hakim, identifikasi, \& implikasi. Jakarta: Komisi Yudisial Republik Indonesia, JPIP, \& USAID.

Sidartha, B.A. (2000). Penalaran hukum dalam sudut pandang keluarga sistem hukum \& penstudi hukum. Bandung: Citra Aditya Bakti.

Soekanto, S., \& Mamudji, S. (2011). Penelitian hukum normatif; Suatu tinjauan singkat. Jakarta: Raja Grafindo.

Tedjosaputro, L. (2003). Etika profesi \& profesi hukum. Semarang: Aneka Ilmu.

Utomo, P. (1992). Etika \& profesi. Jakarta: Gramedia. 